\title{
Pengaruh Penerapan Media Pembelajaran Gerbang Logika Berbasis IT Untuk Meningkatkan Kemampuan Berpikir Dan Hasil Belajar Mahasiswa
}

\author{
Ir. Sulistyaning Kartikawati, MM., M.Pd ${ }^{1)}$, Hendrik Pratama, S.Pd., M.Pd. ${ }^{2)}$ \\ Program Studi Pendidikan Teknik Elektro, FKIP, Universitas PGRI Madiun \\ ${ }^{1)}$ Kartikawati@unipma.ac.id, ${ }^{2)}$ Hendrik@unipma.ac.id
}

\begin{abstract}
Abstrak: Penelitian ini bertujuan untuk mengetahui Pengaruh Penerapan Media Pembelajaran Gerbang Logika Berbasis IT dalam meningkatkan Kemampuan Berpikir Dan Hasil Belajar Mahasiswa. Penelitian ini berbentuk penelitian kuantitatif. Sampel yang digunakan dalam penelitian ini adalah satu kelas yang diambil dengan menggunakan teknik sampling jenuh. Kelas penelitian diberi perlakuan dengan menggunakan media pembelajaran gerbang logika berbasis IT. Adapun variabel bebas dalam penelitian ini adalah media pembelajaran gerbang logika berbasis IT, sedangkan variabel terikatnya adalah kemampuan berpikir dan hasil belajar mahasiswa. Teknik analisis data ada 2 macam yaitu teknik analisa data kemampuan berpikir dan teknik analisa data hasil belajar mahasiswa. Analisis uji hipotesis penelitian ini menggunakan uji-t dengan taraf signifikan $5 \%$. Kriteria uji-t adalah sebagai berikut, Ho diterima/H1 ditolak jika t hitung lebih kecil dari t tabel dan Ho ditolak/H1 diterima jika $\mathrm{t}$ hitung lebih besar dari $\mathrm{t}$ tabel. Dari hasil uji $\mathrm{t}$ untuk kemampuan berpikir diperoleh $\mathrm{t}$ hitung $=15,671$, dan $\mathrm{t}$ tabel $=1,746$, dan hasil uji $\mathrm{t}$ untuk hasil belajar diperoleh $\mathrm{t}$ hitung $=12,33$ dan $\mathrm{t}$ tabel $=1,746$, karena $\mathrm{t}$ hitung lebih besar dari t tabel maka Ho ditolak/H1 diterima, artinya terdapat pengaruh penerapan media pembelajaran gerbang logika berbasis IT dalam meningkatkan kemampuan berpikir dan hasil belajar mahasiswa.
\end{abstract}

Kata kunci : Media gerbang logika, Berbasis IT, Kemampuan Berpikir, Hasil belajar

\section{PENDAHULUAN}

Berpijak dari euforia penggunaan media pembelajaran yang sudah menjadi gaya hidup bagi para pendidik profesional, maka penelitian ini terwujud sebagai satu usaha pemanfaatan teknologi guna meningkatkan mutu pendidikan. Dalam upaya meningkatkan penggunaan media pembelajaran dengan memanfaatkan media pembelajaran berbasis IT sudah sepantasnya bisa dioptimalkan untuk meningkatkan mutu dari sebuah proses pembelajaran.

Media pembelajaran yang popular saat ini adalah media pembelajaran yang menggunakan komputer sebagai penggendali media tersebut salah satunya adalah media Macromedia Flash. Macromedia Flash dirasa cocok sebagai media pembelajaran yang dapat diterapkan agar mutu pembelajaran dan hasil belajar serta faktor-faktor lain dapat meningkat..

Hasil belajar dan kemampuan berfikir peserta didik berfungsi sebagai reaksi terhadap proses pembelajaran yang dilaksanakan pendidik pada saat kegiatan pembelajaran, terutama yang berkaitan dengan metode pembelajaran. Hasil belajar dan kemampuan berpikir pada akhirnya sangat dipengaruhi pemilihan dan penggunaan media pembelajaran yang tepat dan sesuai dengan materi ajar yang akan disampaikan. Peserta didik dapat mencapai hasil belajar yang optimal apabila pendidik tepat dalam menggunakan media pembelajaran.

\section{METODE PENELITIAN}

\subsection{1.Pendahuluan}

Tahapan penelitian mengacu pada Gravemeijer \& Cobb (2006) yang terdiri dari preparing for the experiment (persiapan penelitian), design experiment (pelaksanaan desain eksperimen), 
retrospective analysis (analisis data yang diperoeh dari tahap sebelumnya). Penelitian ini dilakukan di Program Studi Pendidikan Teknik Elektro Universitas PGRI Madiun.

\subsection{Metode Penelitian}

\subsubsection{Populasi}

Populasi dalam penelitian ini adalah mahasiswa semester 4 (empat) di Program Studi Pendidikan Teknik Elektro. Sampel yang diambil terdiri dari 17 mahasiswa sebagai kelas eksperimen. Prosedur pengambilan sampel pada penelitian ini menggunakan teknik sampel jenuh. Pada penerapannya, seluruh mahasiswa mempunyai peluang yang sama untuk diteliti.

\subsubsection{Rancangan Penelitian}

Pada penelitian ini, pendekatan yang digunakan adalah penelitian eksperimental menggunakan desain Control Group pretestposttest. Prosedur pengambilan sampel pada penelitian ini menggunakan teknik purposive sampling. Sampel kelas penelitian/kelas eksperimen diberikan perlakuan dengan menerapkan penggunaan media pembelajaran gerbang logika berbasis IT. Setelah proses pembelajaran pada kelas eksperimen dilaksanakan, maka dihitung nilai rata-rata pencapaian (gain). Variabel bebas dalam penelitian ini yaitu penerapan media pembelajaran gerbang logika berbasis IT. Sedangkan variabel terikat adalah kemampuan berpikir dan hasil belajar mahasiswa.

\subsubsection{Teknik Pengumpulan Data}

Metode Observasi :

Pengumpulan data dengan metode observasi digunakan untuk mengukur sejauh mana pemanfatan media pembelajaran berbasis IT mahasiswa.

Metode Dokumentasi :

Metode dokumentasi digunakan untuk mencari atau mengumpulkan bukti-bukti serta keterangan yang mendukung dalam penelitian ini. Dalam penelitian ini metode dokumentasi digunakan untuk mengumpulkan data nilai mahasiswa semester 3 (tiga) Prodi Pendidikan Teknik Elektro. Nilai tersebut digunakan sebagai acuan untuk melihat kesetaraan dalam pembuatan kelompok penelitian.

Metode Wawancara :

Proses wawancara dilakukan secara bebas, dengan menempatkan situasi tempat dan proses yang terbuka, informal dan tidak terstruktur, tetapi mengarah pada fokus masalah penelitian. Wawancara digunakan untuk mengumpulkan data pemanfaatan media pembelajaran berbasis IT bagi pendidikan dan pandangan mahasiswa terhadap model yang diterapkan.

Metode Angket :

Metode angket digunakan untuk memperoleh data sejauh mana pemanfaatan media pembelajaran berbasis IT dikalangan mahasiswa dan digunakan untuk mengetahui tanggapan mahasiswa terhadap model yang diterapkan. Angket yang digunakan berasal dari berbagai aspek yang sudah dituangkan dalam kisi-kisi. Angket respon mahasiswa ini disusun dengan memilih salah satu jawaban diantara empat jawaban jawaban yang tersedia dengan bobot yaitu: sangat setuju $=4$, setuju $=3$, tidak setuju $=2$, dan sangat tidak setuju $=1$. Sedangkan untuk pernyataan negatif dengan bobot sebaliknya.

Metode Tes :

Metode tes dilakukan pada instrumen tes aspek pengetahuan. Pengambilan tes yang digunakan instrument tes berupa tes bentuk pilihan ganda. Setelah instrument diberikan kepada mahasiswa dapat diperoleh skor nilai secara cepat, obyektif dan mencakup materi 
yang diajarkan. Aspek yang diukur ada 6 (enam), yaitu aspek ingatan $\left(\mathrm{C}_{1}\right)$, aspek pemahaman $\left(\mathrm{C}_{2}\right)$, aspek aplikasi $\left(\mathrm{C}_{3}\right)$, aspek analisis $\left(\mathrm{C}_{4}\right)$, aspek sintesis $\left(\mathrm{C}_{5}\right)$ dan aspek evaluasi $\left(\mathrm{C}_{6}\right)$.

\subsubsection{Teknik Analisis Data}

Teknik analisis yang digunakan dalam penelitian ini adalah:

\section{Analisis angket}

Terdiri dari angket awal pemanfaatan media sosial dan tanggapan mahasiswa terhadap metode yang diterapkan. Teknik analisis data dilakukan dengan lmenghitung skor total ratarata dari setiap komponen dengan menggunakan persamaan:

$$
\bar{X}=\frac{\sum X}{n}
$$

\section{Analisis Data Tes}

Analisis data hasil tes yang digunakan untuk mengukur data kemampuan aspek pengetahuan mahasiswa yang diperoleh dari pretest dan posttest berbentuk soal pilihan ganda. Data pretest dan posttest mahasiswa diuji normalitas dan homogenitas sebagai uji prasyarat analisis. Hasil dari uji prasyarat digunakan sebagai dasar pengujian lebih lanjut menggunakan uji t terhadap hasil belajar kognitif dan kemampuan berpikir mahasiswa.

Hipotesis yang diajukan adalah ada pengaruh penerapan media pembelajaran gerbang logika berbasis IT terhadap kemampuan berpikir dan hasil belajar mahasiswa. Kriteria pengambilan keputusannya yaitu:

a) Jika nilai signifikansi lebih kecil dari 0,05 maka $H_{0}$ ditolak.

b) Jika nilai signifikansi lebih besar dari 0,05 maka $H_{0}$ diterima.

\section{Hasil Dan Pembahasan}

\subsection{Hasil}

\subsubsection{Hasil Belajar Mahasiswa Sebelum Perlakuan (Pretest)}

Data hasil evaluasi terhadap mahasiswa Pendidikan Teknik Elektro semester 4 tahun akademik 2016/2017 menunjukkan bahwa rata-rata hasil belajar mata kuliah Elektronika Logika masih rendah $(53,529)$. Hasil pretes dari 17 mahasiswa terdapat 10 mahasiswa dengan kategori kurang, dan 7 siswa kategori cukup. Data tersebut menunjukkan bahwa proses pembelajaran mata kuliah Elektronika Dasar belum optimal.

\subsubsection{Hasil Belajar Mahasiswa Setelah Perlakuan (Postest)}

Data hasil evaluasi terhadap mahasiswa Pendidikan Teknik Elektro semester 4 tahun akademik 2016/2017 setelah dilakukan perlakuan dalam proses belajar mengajar dengan menggunakan media pembelajaran gerbang logika berbasis IT menunjukkan bahwa rata-rata hasil belajar mata kuliah Elektronika Logika terdapat peningkatan (82,647). Hal ini menunjukkan bahwa terdapat peningkatan nilai rata-rata yang cukup signifikan

\subsubsection{Hasil Kemampuan Berpikir Sebelum Perlakuan (Pretest)}

Data hasil evaluasi terhadap kemampuan berpikir mahasiswa Pendidikan Teknik Elektro semester 4 tahun akademik 2016/2017 menunjukkan bahwa rata-rata pada mata kuliah Elektronika Logika masih cukup $(71,0)$. 


\subsubsection{Hasil Kemampuan Berpikir Setelah Perlakuan (Postest)}

Data hasil evaluasi terhadap kemampuan berpikir mahasiswa Pendidikan Teknik Elektro semester 2 tahun akademik 2016/2017 setelah dilakukan perlakuan dalam proses belajar mengajar menunjukkan bahwa rata-rata nilai kemampuan berpikir mahasiswa pada mata kuliah Elektronika Logika terdapat peningkatan dari 71,0 menjadi 79,5, Hal ini menunjukkan bahwa terdapat peningkatan nilai rata-rata yang cukup signifikan.

\subsection{Hasil Analisa}

\subsubsection{Uji Normalitas dan Homogenitas Hasil Belajar}

Dari hasil uji normalitas pretest hasil belajar mahasiswa diperoleh L hitung sebesar 0,150 dengan $\mathrm{L}$ tabel sebesar 0,213 yang menunjukkan bahwa $\mathrm{L}$ hitung lebih kecil dari $\mathrm{L}$ tabel, artinya sampel terdistribusi normal. Sedangkan untuk posttest diperoleh L hitung sebesar 0,109 dan L tabel 0,213 maka L hitung lebih kecil dari L tabel, artinya sampel terdistribusi normal. Dari uji homogenitas pretest dan posttest diperoleh $\mathrm{F}$ hitung 1,437 dengan $\mathrm{F}$ tabel 2,333. Hal ini menunjukkan $\mathrm{F}$ hitung lebih kecil dari F tabel, artinya sampel homogen.

\subsubsection{Uji Normalitas dan Homogenitas Kemampuan Berpikir}

Dari hasil uji normalitas pretest kemampuan berpikir mahasiswa diperoleh L hitung sebesar 0,147 dengan $\mathrm{L}$ tabel sebesar 0,213 yang menunjukkan bahwa $\mathrm{L}$ hitung lebih kecil dari L tabel, artinya sampel terdistribusi normal. Sedangkan untuk postest diperoleh L hitung sebesar 0,109 dan L tabel 0,213 maka L hitung lebih kecil dari L tabel, artinya sampel terdistribusi normal. Dari uji homogenitas pretest dan postest diperoleh F hitung 1,745 dengan F tabel 2,333. Hal ini menunjukkan F hitung lebih kecil dari F tabel, artinya sampel homogen.

\subsubsection{Uji t untuk Hasil Belajar Mahasiswa}

Dari hasil uji t hasil belajar mahasiswa diperoleh $t$ hitung sebesar 12,33 dengan $t$ tabel sebesar 1,746 yang menunjukkan bahwa t hitung lebih besar dari $t$ tabel, artinya bahwa terdapat pengaruh antara metode dengan hasil belajar.

\subsubsection{Uji t untuk Kemampuan Berpikir Mahasiswa}

Dari hasil uji t kemampuan berpikir kritis mahasiswa diperoleh t hitung sebesar 15,671 dengan t tabel sebesar 1,742 yang menunjukkan bahwa t hitung lebih besar dari t tabel, artinya bahwa terdapat pengaruh antara metode dengan kemampuan berpikir mahasiswa.

\subsection{Pembahasan}

Dari hasil penelitian dan hasil analisis data menunjukkan bahwa uji t dengan $t$ hitung lebih besar dari t tabel dengan taraf signifikansi 5\% menunjukkan bahwa hipotesa nol ditolak atau hipotesa 1 diterima, artinya penerapan media pembelajaran gerbang logika berbasis IT memiliki dampak yang positif dalam meningkatkan kemampuan berpikir dan hasil belajar mahasiswa. Penerapan media pembelajaran gerbang logika berbasis IT memberikan inovasi pembelajaran yang mana dapat merangsang mahasiswa untuk aktif belajar, aktif untuk berpikir, serta aktif di dalam menyelesaikan masalah yang terkait dengan tugas-tugas yang diberikan oleh dosen. Hal ini terlihat bahwa proses belajar mengajar di kelas menunjukkan adanya keaktifan mahasiswa dalam mengikuti proses belajar mengajar dan mahasiswa semakin mampu untuk berpikir dalam menyelesaikan masalah yang diberikan dosen. Sedangkan media pembelajaran yang digunakan dalam proses belajar mengajar memiliki fungsi yang positif sehingga berdampak dalam meningkatkan kemampuan berpikir dan hasil belajar mahasiswa. 
Hasil belajar kognitif serta kemampuan berpikir mahasiswa berdasarkan independent samples test kelas eksperimen sangat signifikan, dan berdasarkan nilai rerata kelas eksperimen memiliki nilai rata-rata kemampuan berpikir dan hasil belajar kognitif lebih tinggi dibandingkan sebelum perlakuan. Hal ini menunjukkan penerapan media pembelajaran gerbang logika berbasis ITdalam meningkatkan kemampuan berpikir dan hasil belajar mahasiswa berhasil dengan baik. Oleh sebab itu penerapan media pembelajaran gerbang logika berbasis IT dapat dinyatakan dapat membuat mahasiswa lebih berkonsentrasi dalam memahami materi yang diberikan dosen, dapat mengembangkan kemampuan berpikir serta hasil belajar.

\section{Kesimpulan dan Saran}

\subsection{Kesimpulan}

Hasil penelitian menunjukkan bahwa terdapat pengaruh yang signifikan antara penggunaan media pembelajaran gerbang logika berbasis IT terhadap hasil belajar dan kemampuan berpikir mahasiswa.

\subsection{Saran}

Proses jangka panjang bisa dikembangkan sistem evaluasi dan penilaian berbasis IT. Penilaian dilakukan secara online dengan aturan yang ditentukan dosen untuk melatih kemandirian belajar mahasiswa. Soal bisa disesuaikan dengan kemampuan berpikir masingmasing mahasiswa.

Perlu dilakukan pengembangan model pembelajaran yang terintegrasi media berbasis IT yang lain untuk memotivasi mahasiswa dalam belajar sehingga berkembangnya media berbasis IT menjadi hal yang positif, tidak untuk ditakuti, dan bisa digunakan sebagai sarana dalam meningkatkan hasil belajar.

\section{DAFTAR PUSTAKA}

Arikunto, S. (2013). Prosedur Penelitan. Jakarta: PT Rineka Cipta.

Hamzah \& Nina. (2010). Teknologi Komunikasi \& Informasi Pembelajaran. Jakarta: PT Bumi Aksara.

Munir. (2008). Kurikulum Berbasis Teknologi Informasi dan Komunikasi. Bandung: Alfabeta.

Rahman dkk. (2008). Optimasi Macromedia Flash Untuk Mendukung Pembelajaran Berbasis Komputer Pada Program Studi Ilmu Komputer FPMIPA UPI. Jurnal Pendidikan Teknologi Informasi dan Komunikasi. Volume 1, Nomor 2.

(http://file.upi.edu/Direktori/FPMIPA/PRODI._ILMU_KOMPUTER/196601011991031-

WAWAN_SETIAWAN/12._Optimalisasi_Flash.pdf) diunduh pada 14 Agustus 2017

Robertus \& Kosasih. (2017). Optimalisasi Media Pembelajaran. Jakarta: PT Grasindo.

Siregar. (2014). Statistik Parametrik Untuk Penelitian Kuantitatif. Jakarta: PT Bumi Aksara.

Sundayana. (2015). Statistika Penelitian Pendidikan. Bandung: PT Alfabeta.

Teknologi Informasi. 2005 http://id.wikipedia.org/wiki/Teknologi_informasi 